\title{
Ceramic Tiles Production from Cullet and Agricultural Wastes Obtained from Wheat and Sugarcane Cultivation
}

\author{
M. H. ROUSHDY \\ Chemical Engineering Department, Faculty of Engineering \\ The British University in Egypt (BUE) \\ El-Sherouk 11837, Cairo, EGYPT
}

\begin{abstract}
Agricultural wastes are a big source for environmental pollution so it's a good choice to recycle them so as to get an environmental and economic benefit. The purpose of this research is to determine the possibility of recycling two types of agriculture wastes obtained from wheat and sugarcane cultivation in addition to broken glass (cullet) as raw materials for ceramic wall tiles production. The used agriculture wastes are the agricultural residue obtained from wheat and sugarcane cultivation. The experimental work starts with performing XRF and sieve analysis for all raw materials. Ceramic wall tiles specimens were made with dimensions $110.4 \times 55.4 \times 8 \mathrm{~mm}^{3}$ using $27 \mathrm{MPa}$ dry pressing then dried at $120{ }^{\circ} \mathrm{C}$ overnight, then fired using firing temperatures equal to $1100{ }^{\circ} \mathrm{C}$ or $1150{ }^{\circ} \mathrm{C}$ during 15 min soaking time. Water absorption, apparent porosity, and mechanical properties were done to compare them with ISO standards. According to the previous experimental work, it was found that the samples with the composition (10\% Cullet, 15\% Wheat ash straw, $20 \%$ sugarcane) for samples that fired at $1150{ }^{\circ} \mathrm{C}$ or $(10 \%$ Cullet, $13 \%$ Wheat ash straw, $18 \%$ sugarcane $)$ for samples that fired at $1100{ }^{\circ} \mathrm{C}$ has the optimum properties.
\end{abstract}

Key-Words: Wheat Straw; Sugarcane; Cullet; Wall tiles; ISO standard; Optimization

Received: November 30, 2020. Revised: April 14, 2021. Accepted: April 27, 2021. Published: May 4, 2021.

\section{Introduction}

Ceramics are known as inorganic and non-metallic materials, which are the main materials in our daily lifestyle. The material engineers are the designers for every process in for these products formation. They are there to create new products of ceramics and to find out many different usages for the ceramic products in our daily life [1].

The main raw material for the ceramics products are clays which are the main body of the ceramic products, feldspars which is used as fluxing components for their ability to melt at low temperature, and sand which is used as the main glass forming raw material. Some other raw materials might be used such as the dolomite and the limestone [2].

White wares, refractory products, and glasses are examples of traditional ceramics. Wall and floor tiles which are known as white wares are used for interior and exterior decoration. Recently, however, some ceramic products could be prepared from nonsilicate raw materials and sometimes even without firing. That is why the traditional view towards ceramics has changed so that nowadays a ceramic material is defined as being an inorganic nonmetallic solid [3].
Egyptians, the Babylonians, and the Assyrians are the first producers for ceramic tiles. The Step Pyramid for the Pharaoh Zoser that was built by ancient Egyptian around 2600 B.C., contained colorful glazed tiles. European country and the United States manufactured ceramic tiles later. Today, tile manufacture is highly automated [4]. Amin et al. re-used Waste sludge in the floor and wall tiles production. It was found it is possible to produce floor tiles contains $20 \%$ sludge and wall tiles contains $10 \%$ sludge [5]. Roushdy (2019a) investigated using mixture of roller kilns waste and ceramic tiles sludge as a raw materials for floor tiles production. The results shows that the optimum samples have composition of $64 \%$ Floor tiles mixture, 35\% Ceramic tiles sludge, and $1 \%$ Roller Kiln or $74 \%$ Floor tiles mixture, $24 \%$ Ceramic tiles sludge, and 2\% Roller Kiln [6]. Roushdy (2019 b) examined the possibility of using a mixture of roller kilns, ceramic tiles sludge, and sanitary ware waste powder as raw materials for floor tiles production. The results shows that the optimum samples have composition of $44 \%$ Floor tiles mixture, 39\% Ceramic tiles sludge, 15\% sanitary ware waste, and 2\% Roller Kiln [7]. Allam et al. investigate producing roof tile samples from ordinary Portland cement (OPC) with Marble Waste Slurry with composition in range of $5-25 \%$, and 
roof tiles from sand with Marble Waste Slurry with composition in range of 5-40\%. All mechanical tests should that roof tile samples containing MWS as a partial replacement for sand and cement were complied with the ASTM standard limits till 20\% replacement ratio [8].

The main substrates of human diet are sugar. China, Brazil, Australia, Thailand and India are the top five countries in the world in sugar producing. At the year 710 AD Egypt started sugar production [9]. Sugar cane was a source of sugar in sugar production since 1981. Some areas of Upper Egypt are famous with cane plantations as the amount of cultivated cane was 16 million tons in 2009 [10; 11]. On the other hand, Egypt is famous with wheat cultivation as it occupies about $32.6 \%$ of the total winter land area. Wheat straw ash is considered as the most important agricultural residues. Straw consists mainly of lignin, hemicelluloses, and cellulose [12].

Hassan et al. (2018) investigate the use of sugarcane bagasse and wheat straw in the fireclay bricks production. Results proved that adding 5\% bagasse with $0.5 \%$ polystyrene beads results and firing for 2 hours at $1250^{\circ} \mathrm{C}$ produced bricks abiding by ASTM standards for C-32 type insulating fireclay bricks. On the other hand, the addition of 5\% wheat straw, despite fulfilling the density and thermal conductivity requirements, resulted in marginal values for cold crushing strength [13]. Micheal and Moussa integrated sugarcane bagasse with cement in the production brick. The results showed that replacing cement with $1.5 \%$ sugarcane bagasse will give the bricks with a good mechanical properties and higher strength [14]. Dawoud et al. (2020) summarized the techniques used by many researcher's to replace cement with sugarcane bagasse during building bricks production and showed the best procedures for partially replacing cement with sugarcane bagasse which give the best properties of cement bricks [15].

The main objective of the present study is to investigate the possibility of recycling two types of agriculture wastes obtained from wheat and sugarcane cultivation in addition to broken glass (cullet) as raw materials for ceramic wall tiles production.

\section{Experimental Work}

\subsection{Raw Materials}

The four types of raw materials that used in this research are the following:

[1] Mixed raw materials provided from ceramic tiles factory. This type of ceramic wall tiles basic mixture was prepared from Egyptian raw materials as shown in Table 1.

[2] Cullet which is waste broken glass.

[3] Agricultural residue obtained from wheat cultivation.

[4] Agricultural residue obtained from sugarcane cultivation.

Table 1.wall Tiles composition

\begin{tabular}{|l|l|}
\hline Raw Materials & Wt. \% \\
\hline Aswan Clay & 25 \\
\hline Ball Clay & 35 \\
\hline Glass Sand & 15 \\
\hline Potash Feldspar & 14 \\
\hline Limestone & 9 \\
\hline Bentonite & 2 \\
\hline
\end{tabular}

\subsection{Characterization of Raw Materials}

$\mathrm{XRF}$ method was used to determine the chemical composition of all raw materials by Wavelength Dispersive (WD-XRF) Sequential Spectrometer. The distribution of particle size for all the raw materials was determined using BT-2001 Laser Particle Size Analyzer according to ASTM D 422 (2007) [16].

\subsection{Ceramic Tiles Preparation}

The formation of wall tiles was done by the following steps:

[1] Molding the samples of ceramic tiles by a mold with dimensions $11.04 \times 5.54 \times 0.8 \mathrm{~cm}^{3}$ pressed under $27 \mathrm{MPa}$ using automatically hydraulic press.

[2] Drying the tile samples using a laboratory dryer on two steps. Mild Drying at $70{ }^{\circ} \mathrm{C}$ for 4 hours, then drastic drying at $110^{\circ} \mathrm{C}$ for one hour. 
[3] Firing the tile samples using heating rates so close to industrial conditions by Prothermelectrical furnace model PLF 14015. The firing technique used for the preparation of wall tiles samples using the single fast firing. The firing schedule can be described as follows that simulates conditions in a roller kiln:

- Fast temperature increasing to $550{ }^{\circ} \mathrm{C}$.

- Slow temperature increasing from $550{ }^{\circ} \mathrm{C}$ to $750{ }^{\circ} \mathrm{C}$ in order to prevent crack formation by slow combined water escape.

- Fast temperature increasing from $750{ }^{\circ} \mathrm{C}$ to $900{ }^{\circ} \mathrm{C}$.

- Slow temperature increasing from $900{ }^{\circ} \mathrm{C}$ to $1000{ }^{\circ} \mathrm{C}$, in order to prevent crack formation by provide suitable time for calcination of calcium carbonate.

- Fast temperature increasing to the target firing temperature $\left(1100{ }^{\circ} \mathrm{C}\right.$ or $\left.1150{ }^{\circ} \mathrm{C}\right)$ during soaking time of 15 Minutes.

\subsection{Ceramic Tiles Testing}

ASTM C 373 (2017) was used to determine the percent water absorption and open porosity while ISO 10545 - 4 (2014) was used to determine breaking strength and modulus of rupture (MOR) $[17 ; 18]$.

\section{Results and Discussion}

\subsection{Ceramic Raw Materials Chemical Composition}

The Chemical analysis results for the raw materials are shown in tables 2, 3, and 4. The following conclusions can be drawn:

Table 2 shows the chemical analysis of a standard wall tile mix. The loss on ignition happened because of chemical water of clays loss and carbon dioxide loss from limestone. As can be seen from this table, silica, alumina, calcium oxide and iron oxide constitute more than 96 percent of the mix (on loss on ignition - free basis). The loss on ignition is due to calcination of limestone and loss of chemical water from clay.

For cullet, silica is the main component as shown in Table 2.

Sugarcane bagasse waste is mainly composed of lignin, cellulose, hemicelluloses, fats and silica. Its ultimate composition was established as shown in Table 3.

Wheat straw samples are mainly composed of lignin, cellulose, hemicelluloses, proteins and sugars. Its ultimate composition was established as shown in Table 4.

Table 2: Chemical composition of Wall Mix and Cullet

\begin{tabular}{|c|c|c|}
\hline Main constituents & Cullet & Wall mix \\
\hline $\mathrm{SiO}_{2}$ & 73.58 & 60.25 \\
\hline $\mathrm{Al}_{2} \mathrm{O}_{3}$ & 1.24 & 15.69 \\
\hline $\mathrm{Fe}_{2} \mathrm{O}_{3}$ & 0.23 & 3.59 \\
\hline $\mathrm{TiO}_{2}$ & 0.04 & 1.4 \\
\hline $\mathrm{MnO}$ & 0.007 & ----- \\
\hline $\mathrm{SO} 3$ & 0.42 & 0.04 \\
\hline $\mathrm{MgO}$ & 0.17 & 0.58 \\
\hline $\mathrm{CaO}$ & 7.42 & 5.89 \\
\hline $\mathrm{Na}_{2} \mathrm{O}$ & 15.84 & 0.53 \\
\hline $\mathrm{K}_{2} \mathrm{O}$ & 0.05 & 0.67 \\
\hline $\mathrm{Cl}$ & 0.06 & ----- \\
\hline $\mathrm{P}_{2} \mathrm{O}_{5}$ & 0.02 & 0.13 \\
\hline $\mathrm{LOI}$ & ----- & 11.18 \\
\hline & \multicolumn{2}{|c}{} \\
\hline
\end{tabular}

Table 3: Chemical Analysis of Sugarcane Bagasse Waste

\begin{tabular}{|c|c|}
\hline Main constituents & Sugarcane Bagasse \\
\hline Carbon & 48.7 \\
\hline Silica & 44 \\
\hline Nitrogen & 1.3 \\
\hline Hydrogen & 4.9 \\
\hline Phosphorous & 1.1 \\
\hline
\end{tabular}

Table 4: Chemical Analysis of wheat straw

\begin{tabular}{|c|c|}
\hline Main constituents & Wheat Straw Ash \\
\hline Carbon & 49 \\
\hline Hydrogen & 5.3 \\
\hline Oxygen & 37 \\
\hline Silica & 1.6 \\
\hline Sulfur & 0.66 \\
\hline Potassium & 0.52 \\
\hline
\end{tabular}

\subsection{Particle Size Distribution for Raw Materials}

Figure 1 shows the cumulative screen analysis of all raw materials. The mean particle size of wall tiles mixture is much higher than any type of waste powder so it was expected that the addition of wastes to the main raw materials will decrease the porosity of the mixture. 


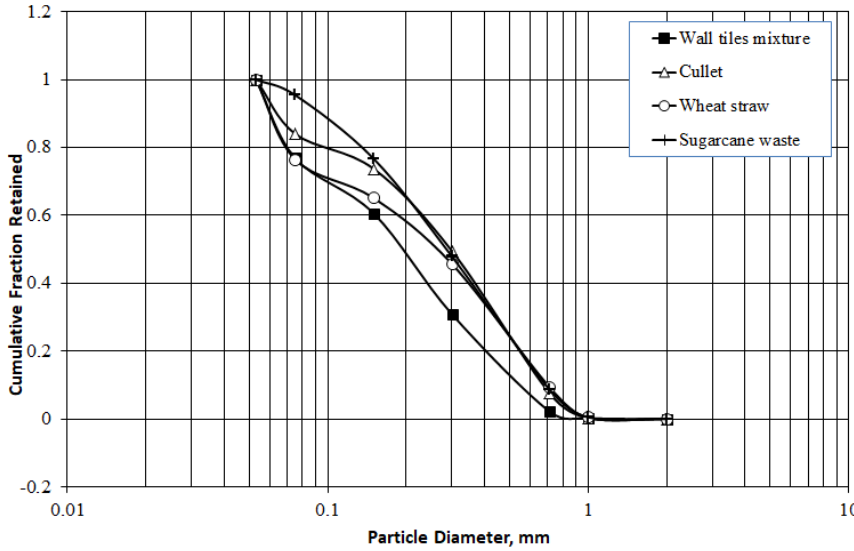

Figure 1. Cumulative Analysis of Raw Materials

\subsection{Green Breaking Strength and Modulus of Rupture (MOR)}

The values of green MOR are higher than $1 \mathrm{MPa}$ so the tiles will face less broken on conveying.

\subsection{Water Absorption and Apparent Porosity}

Cullet (C) or waste glass addition to the samples increase the liquid phase formation then decreases the porosity. On other hand, there was more liquid phase formation accompanied with dilation in closed pores and expansion due to the entrapment of released gases, mainly $\mathrm{CO}_{2}$, which in turn increase the porosity and hence increase the water absorption. The thermal treatment of waste glass at high temperature released volatile matter which promoted porous structure. Addition of cullet more than $10 \%$ results in samples warping.

Addition of wheat straw ash (W) increases the porosity and hence the water absorption. According to the chemical analysis done, the results showed that it contains mainly carbon and oxygen so its addition to the samples increases the amount of gases produced and then increases the porosity and water absorption.

Addition of sugarcane bagasse waste ash (S) increases the porosity but with little effect than wheat straw ash and hence the water absorption. According to the chemical analysis done, the results showed that it contains mainly carbon and silica so its addition to the samples increases the amount of gases produced and then increases the porosity and water absorption.

According to Egyptian standards (ISO13006/2012) [18] the values of obtained water absorption was found to be in the category of tiles with high water absorption, $\mathrm{E}>10 \%$. These results are presented in following tables.
The equations related each waste percent and percent open porosity $(\mathrm{P})$ using Excel program are the following

$$
\begin{aligned}
& P, 1100^{\circ} C=27.12326+0.04999 C+ \\
& 0.06947 W+0.06892 S \\
& P, 1150^{\circ} C=26.05626+0.04803 C+ \\
& 0.06674 W+0.06621 S
\end{aligned}
$$

\begin{tabular}{|c|c|c|c|c|c|}
\hline \multirow{2}{*}{\multicolumn{4}{|c|}{ Percentage }} & \multirow{3}{*}{$\begin{array}{c}\text { Firing } \\
\text { Temperature, } \\
{ }^{\circ} \mathrm{C}\end{array}$} & \multirow{3}{*}{$\begin{array}{c}\text { Percent } \\
\text { Open } \\
\text { Porosity }\end{array}$} \\
\hline & & & & & \\
\hline $\begin{array}{l}\text { Main } \\
\text { Body }\end{array}$ & (C) & (W) & $(\mathrm{S})$ & & \\
\hline 100 & 0 & 0 & 0 & 1100 & 27.123 \\
\hline 90 & 10 & 0 & 0 & 1100 & 27.812 \\
\hline 80 & 0 & 20 & 0 & 1100 & 28.512 \\
\hline 70 & 10 & 20 & 0 & 1100 & 29.201 \\
\hline 80 & 0 & 0 & 20 & 1100 & 28.123 \\
\hline 70 & 10 & 0 & 20 & 1100 & 28.812 \\
\hline 60 & 0 & 20 & 20 & 1100 & 29.512 \\
\hline 50 & 10 & 20 & 20 & 1100 & 30.201 \\
\hline 100 & 0 & 0 & 0 & 1150 & 26.056 \\
\hline 90 & 10 & 0 & 0 & 1150 & 26.718 \\
\hline 80 & 0 & 20 & 0 & 1150 & 27.391 \\
\hline 70 & 10 & 20 & 0 & 1150 & 28.053 \\
\hline 80 & 0 & 0 & 20 & 1150 & 27.016 \\
\hline 70 & 10 & 0 & 20 & 1150 & 27.678 \\
\hline 60 & 0 & 20 & 20 & 1150 & 28.351 \\
\hline 50 & 10 & 20 & 20 & 1150 & 29.013 \\
\hline
\end{tabular}

Table 5: Effect of wastes addition on percent open porosity

The equations related each waste percent and water absorption (WA) using Excel program are the following

$$
\begin{aligned}
& W A, 1100^{\circ} C=14.42581+0.04032 \mathrm{C}+ \\
& 0.05936 \mathrm{~W}+0.04886 \mathrm{~S} \\
& W A, 1150^{\circ} C=13.94170+0.03896 \mathrm{C}+ \\
& 0.05737 \mathrm{~W}+0.04722 \mathrm{~S}
\end{aligned}
$$

From the previous equations it was found than the addition of wheat straw ash has the highest effect on porosity and water absorption then the sugarcane waste then cullet. 
Table 6: Effect of wastes addition on water absorption

\begin{tabular}{|c|c|c|c|c|c|}
\hline \multicolumn{4}{|c|}{ Percentage } & \multirow{2}{*}{$\begin{array}{c}\text { Firing } \\
\text { Temperature, } \\
{ }^{\circ} \mathrm{C}\end{array}$} & \multirow{2}{*}{$\begin{array}{c}\text { Percent } \\
\text { Water } \\
\text { Absorption }\end{array}$} \\
\hline $\begin{array}{l}\text { Main } \\
\text { Body }\end{array}$ & (C) & (W) & $(\mathrm{S})$ & & \\
\hline 100 & 0 & 0 & 0 & 1100 & 14.425 \\
\hline 90 & 10 & 0 & 0 & 1100 & 14.914 \\
\hline 80 & 0 & 20 & 0 & 1100 & 15.612 \\
\hline 70 & 10 & 20 & 0 & 1100 & 16.101 \\
\hline 80 & 0 & 0 & 20 & 1100 & 15.232 \\
\hline 70 & 10 & 0 & 20 & 1100 & 15.720 \\
\hline 60 & 0 & 20 & 20 & 1100 & 16.419 \\
\hline 50 & 10 & 20 & 20 & 1100 & 16.907 \\
\hline 100 & 0 & 0 & 0 & 1150 & 13.941 \\
\hline 90 & 10 & 0 & 0 & 1150 & 14.413 \\
\hline 80 & 0 & 20 & 0 & 1150 & 15.089 \\
\hline 70 & 10 & 20 & 0 & 1150 & 15.561 \\
\hline 80 & 0 & 0 & 20 & 1150 & 14.720 \\
\hline 70 & 10 & 0 & 20 & 1150 & 15.193 \\
\hline 60 & 0 & 20 & 20 & 1150 & 15.868 \\
\hline 50 & 10 & 20 & 20 & 1150 & 16.340 \\
\hline
\end{tabular}

\subsection{Fired Breaking Strength and Modulus of \\ Rupture}

The following tables show that the bending strength or MOR decrease by the increase in waste percent. When the porosity increases and then the strength decreases. According to Egyptian standards (ISO13006/2012) [18] the values of breaking strength must exceed the minimum value of $200 \mathrm{~N}$ and the values of MOR must exceed the minimum value of $15 \mathrm{MPa}$ for tiles of category with \%WA > $10 \%$.

The equations related each waste percent and modulus of rupture (MOR) using Excel program are the following

$$
\begin{aligned}
& M O R, 1100^{\circ} C=17.10553-0.05232 C- \\
& 0.08466 W-0.05966 S \\
& M O R, 1150^{\circ} C=18.29934-0.05597 C- \\
& 0.09057 W-0.06382 S
\end{aligned}
$$

\begin{tabular}{|c|c|c|c|c|c|}
\hline \multicolumn{4}{|c|}{ Percentage } & \multirow{2}{*}{$\begin{array}{c}\text { Firing } \\
\text { Temperature, } \\
{ }^{\circ} \mathrm{C}\end{array}$} & \multirow{2}{*}{$\begin{array}{c}\text { MOR } \\
\left(\mathrm{N} / \mathrm{mm}^{2}\right)\end{array}$} \\
\hline $\begin{array}{l}\text { Main } \\
\text { Body }\end{array}$ & $\mathrm{C}$ & $\mathrm{W}$ & $\mathrm{S}$ & & \\
\hline 100 & 0 & 0 & 0 & 1100 & 17.105 \\
\hline 90 & 10 & 0 & 0 & 1100 & 16.582 \\
\hline 80 & 0 & 20 & 0 & 1100 & 15.412 \\
\hline 70 & 10 & 20 & 0 & 1100 & 14.889 \\
\hline 80 & 0 & 0 & 20 & 1100 & 15.912 \\
\hline 70 & 10 & 0 & 20 & 1100 & 15.389 \\
\hline 60 & 0 & 20 & 20 & 1100 & 14.219 \\
\hline 50 & 10 & 20 & 20 & 1100 & 13.695 \\
\hline 100 & 0 & 0 & 0 & 1150 & 18.299 \\
\hline 90 & 10 & 0 & 0 & 1150 & 17.739 \\
\hline 80 & 0 & 20 & 0 & 1150 & 16.488 \\
\hline 70 & 10 & 20 & 0 & 1150 & 15.928 \\
\hline 80 & 0 & 0 & 20 & 1150 & 17.022 \\
\hline 70 & 10 & 0 & 20 & 1150 & 16.463 \\
\hline 60 & 0 & 20 & 20 & 1150 & 15.211 \\
\hline 50 & 10 & 20 & 20 & 1150 & 14.651 \\
\hline
\end{tabular}

Table 7: Effect of wastes addition on MOR

The equations related each waste percents and breaking strength (BS) using Excel program are the following

$B S, 1100^{\circ} C=410.16023-3.87418 C-$

$6.21997 W-5.94340 S$

$B S, 1150^{\circ} \mathrm{C}=472.10978-5.01585 \mathrm{C}-$

$8.27934 W-6.38507 S$

From the previous equations it was found than the addition of wheat straw ash has the highest effect on breaking strength and MOR then the sugarcane waste then cullet. 
Table 8: Effect of wastes addition on breaking strength

\begin{tabular}{|c|c|c|c|c|c|}
\hline \multicolumn{4}{|c|}{ Percentage } & \multirow{2}{*}{$\begin{array}{c}\text { Firing } \\
\text { Temperature, } \\
{ }^{\circ} \mathrm{C}\end{array}$} & \multirow{2}{*}{$\begin{array}{l}\text { Breaking } \\
\text { Strength, } \\
\text { (N) }\end{array}$} \\
\hline $\begin{array}{l}\text { Main } \\
\text { Body }\end{array}$ & $\mathrm{C}$ & W & $\mathrm{S}$ & & \\
\hline 100 & 0 & 0 & 0 & 1100 & 374.291 \\
\hline 90 & 10 & 0 & 0 & 1100 & 352.125 \\
\hline 80 & 0 & 20 & 0 & 1100 & 310.812 \\
\hline 70 & 10 & 20 & 0 & 1100 & 205.406 \\
\hline 80 & 0 & 0 & 20 & 1100 & 335.425 \\
\hline 70 & 10 & 0 & 20 & 1100 & 263.562 \\
\hline 60 & 0 & 20 & 20 & 1100 & 191.538 \\
\hline 50 & 10 & 20 & 20 & 1100 & 178.044 \\
\hline 100 & 0 & 0 & 0 & 1150 & 429.139 \\
\hline 90 & 10 & 0 & 0 & 1150 & 403.725 \\
\hline 80 & 0 & 20 & 0 & 1150 & 356.358 \\
\hline 70 & 10 & 20 & 0 & 1150 & 235.255 \\
\hline 80 & 0 & 0 & 20 & 1150 & 384.578 \\
\hline 70 & 10 & 0 & 20 & 1150 & 261.804 \\
\hline 60 & 0 & 20 & 20 & 1150 & 219.355 \\
\hline 50 & 10 & 20 & 20 & 1150 & 200.443 \\
\hline
\end{tabular}

\section{Conclusion}

The main aim of this research is to investigate the possibility of recycling two types of agrculture wastes in addition to broken glass (cullet) as part of raw materials for ceramic wall tiles production. The used agriculture wastes are the agricultural residue obtained from wheat and sugarcane cultivation.

The experimental work starts with performing XRF and sieve analysis for all raw materials. Ceramic wall tiles specimens were made with dimensions $110.4 \times 55.4 \times 8 \mathrm{~mm}^{3}$ using $27 \mathrm{MPa}$ dry pressing then dried at $120{ }^{\circ} \mathrm{C}$ overnight. Tile samples were fired at temperatures in range off $1100{ }^{\circ} \mathrm{C}-1150{ }^{\circ} \mathrm{C}$ for 15 min soaking time. Water absorption, apparent porosity, and mechanical properties were done to compare them with ISO standards.

According to the previous experimental work, it was found that the samples with the composition (10\% Cullet, 15\% Wheat ash straw, 20\% sugarcane) for samples that fired at $1150{ }^{\circ} \mathrm{C}$ or $(10 \%$ Cullet, $13 \%$ Wheat ash straw, 18\% sugarcane) for samples that fired at $1100{ }^{\circ} \mathrm{C}$ has the optimum properties.

\section{Acknowledgments}

The author would like to acknowledge the British University in Egypt (BUE) for funding this research through young investment research grand (YIRG) and also Ceramica Venus Company due to their support and providing facilities required to perform this work. The author would like to thank Prof. Magdi F. Abadir for everything. The author is proud to be his student.

\section{References:}

[1] Elijah., Proposed Best Available Techniques. Retrieved from CERAME-UNIE: http://eippcb.jrc.ec.europa.eu/reference/BREF/c er_bref_0807.pdf , 2004

[2] Shreve, R. N., Ceramic Engineering and Science Proceedings, Volume 28, Issue 10. Ceramic Engineering and Science Proceeding, 2010

[3] Abadir M.F., "Elements of Ceramic Technology", Cairo University, Faculty of Engineering, 6th Ed., 2011.

[4] Ceramic Tile,. Retrieved from http://www.madehow.com/Volume-1/CeramicTile.html\#b , 2012

[5] Amin, S.H.K., Elmahgary, M.G., Abadir, M.F., "Preparation and characterization of dry pressed ceramic tiles incorporating ceramic sludge waste", Ceramics - Silikaty, Vol 63, No. 1, 2019, pp 11-20

[6] Roushdy, M.H., "Recycling of the mixture resulted from roller kiln waste and ceramic tiles sludge waste in the manufacturing of ceramic floor tiles", International Journal of Innovative Technology and Exploring Engineering, Vol 8, No. 9, July 2019 a, pp 1132-1138

[7] Roushdy, M.H., "Recycling of the mixture resulted from sanitary ware waste, roller kiln waste and ceramic tiles sludge waste in the manufacturing of ceramic floor tiles", International Journal of Innovative Technology and Exploring Engineering, Vol 8, No. 11, September 2019 b, pp 379-386.

[8] Allam, M.E., Amin, S.K., Garas, G., "Testing of cementitious roofing tile specimens using marble waste slurry", International Journal of Sustainable Engineering, Vol 13, No. 2, 3 March 2020, pp 151-157.

[9] Hassan, S.F., Nasr, M.I., "Sugar Industry in Egypt" Sugar Tech, 2008, 10(3): 204-209.

[10] Hamada, Y.M., "Water Resources Reallocation in Upper and Middle Egypt." EWRA European Water, EW Publications, 2011, 33: 33-44

[11] Economic and Social Commission for Western Asia (ESCWA). "Increasing the 
competitiveness of small and medium-sized enterprises through the use of environmentally sound technologies: assessing the potential for the development of second-generation biofuels in the ESCWA region" United Nations, New York, 2009.

[12] Xiao, B., Sun, X.F., Sun, R.C., "Chemical, structural and thermal characterization of alkali soluble lignins and hemicelluloses and cellulose from maize stems, rye straw and rice straw". Polymer Degradation and Stabilization, 2001, 74, 307-319

[13] Hassan A. M., Abadir M. F., Moselhy H.., 2018 "Use of Agricultural Waste in the Preparation of Insulating Fireclay Bricks". International Journal of Applied Engineering Research, 2018, Volume 13, Number 12, pp. 10819-10825.

[14] Micheal A., Moussa R. R., 2021 "Investigating the Economic and Environmental Effect of Integrating Sugarcane Bagasse (SCB) Fibers in Cement Bricks". Ain shams Engineering journal, Article in Press.

[15] Dawoud N., Micheal A., Moussa R. R., "A Review on Investigating the experimental process for partial replacement of cement with sugarcane bagasse in the construction industry". 13th International Conference on Civil and Architecture Engineering (ICCAE-13), IOP Conf. Series: Materials Science and Engineering 974.

[16] ASTM D 422 / 1963 (Reapproved 2007), "Method for particle-size analysis of soils", ASTM Annual book, U.S.A., 4 (8).

[17] ASTM C 373 / 2017, "Standard test methods for determination of water absorption and associated properties by vacuum method for pressed ceramic tiles and glass tiles and boil method for extruded ceramic tiles and non-tile fired ceramic white-ware products", ASTM Annual book, U.S.A., 15 (2).

[18] ISO 10545 - 4 / 2014, "Ceramic tiles - Part 4: Determination of modulus of rupture and breaking strength", International Organization for Standardization (ISO), Geneva.

Creative Commons Attribution License 4.0 (Attribution 4.0 International, CC BY 4.0)

This article is published under the terms of the Creative Commons Attribution License 4.0 https://creativecommons.org/licenses/by/4.0/deed.en US 